\title{
Students' opinions on blended learning and its implementation in terms of their learning styles
}

\author{
Benlihan Uğur • Buket Akkoyunlu • \\ Serap Kurbanoğlu
}

\begin{abstract}
The purpose of this article is to examine students' views on the blended learning method and its use in relation to the students' individual learning style. The study was conducted with 31 senior students. Web based media together with face to face classroom settings were used in the blended learning framework. A scale of Students' Views on Blended Learning and its implementation, Kolb's Learning Style Inventory, Pre-Information Form and open ended questions were used to gather data. The majority of the students' fell into assimilators, accommodators and convergers learning styles. Results revealed that students' views on blended learning method and its use are quite positive.
\end{abstract}

Keywords Blended learning $\cdot$ E -learning $\cdot$ Learning styles $\cdot$ Hybrid learning · Kolb's learning style

\section{Introduction}

21st-century brings different challenges for universities. Many institutions are responding to the pressures by embracing the new technologies. Technology has a

\footnotetext{
B. Uğur • B. Akkoyunlu ( $\bowtie)$

Faculty of Education, Hacettepe University, Ankara, Turkey

e-mail: buket@hacettepe.edu.tr

B. Uğur

e-mail: benlinin@hotmail.com

S. Kurbanoğlu

Faculty of Letters, Hacettepe University, Ankara, Turkey

e-mail: serap@hacettepe.edu.tr
} 
vital role to play in building up 21 st-century skills, broadening access to education and personalizing the learning experience to adapt teaching to the unique needs of each learner. Besides, today's students come pre-skilled with technology proficiencies to universities and a built in acceptance for new technology. Descriptions of learners have tended to focus on whether or not they are the "Digital Natives", "Digital Immigrants", "Generation N", "Net Generation", "Grasshopper Mind", "Millennial Generation" (Prensky 2001, Caldwell et al 2006; Toman et al 2005; Raines 2005). Their expectations are also different on how, where and when technology could be used within their course. As universities we may make assumptions about what today's students want from and do with technologies (Oblinger and Hawkins 2005).

There have been a number of factors impeding the large quantity of technology in education across all sectors as well as universities. In recent times, factors (such as information explosion, twenty first century skills, demands of workplaces, easy access to technology) have emerged which have strengthened and encouraged moves to adopt technologies into classrooms and learning settings.

These have included a growing need to explore efficiencies in terms of program delivery, the opportunities for flexible delivery provided by technologies (Oliver and Short 1996); the capacity of technology to provide support for customized educational programs to meet the needs of individual learners (Kennedy and McNaught 1997); and the growing use of the Internet and WWW as tools for information access and communication. The rapid growth in the use of learning technologies, particularly the use of the Internet and web-based communication, has provided teachers and students with many more opportunities to explore the most suitable teaching and learning methodologies and also mix of teaching and learning styles for a given task. The development of internet technologies and faster internet connections have resulted in the delivery of a great majority of distance learning being conducted via the internet. Besides, these technologies have also changed teaching paradigms. The paradigm shift away from teaching to an emphasis on learning has encouraged power to be moved from the teacher to the student. Because of all these reasons mentioned above universities are taking advantage of technology to enhance communication with their students, to improve the quality of learning by making it relevant to the skills and knowledge needed in 21 st-century . The delivery of education via the Internet has taken on increasing importance for universities. With ths increased importance, universities gave great attention to online learning in during the first decade of the 21 st century.

Online learning which allows learners to have access for educational content and have one way or two way communication with other learners and instructors, through computer networks, intranet, internet and www, provides quick, easy and flexible access for all kinds of content through digital devices, such as CD-ROMs, DVDs, computers and mobile phones. Although online learning have many benefits in means of flexible interaction, various media usage etc. there are still some obstacles in designing online learning (Karadeniz 2009) such as technical (design the content based on video, animation or simulations and use videoconferences frequently because of the low bandwidth of network) and social (absence of human interaction) problems. While online learning ensures flexibility and competency 
which are difficult to ensure in a real class setting, face to face education enables social interaction which is required as guidance for students. Some studies underlined that technology and interaction type should be taken into consideration in order to design effective, attractive and efficient learning environments (Karadeniz 2009; Bliuc et al. 2007; Ginns and Ellis 2007). The best aspects of both face to face and online learning and the integration of e-learning into traditional learning programs with the development of new delivery communication technology systems have created blended learning.

Generally, blended learning is defined as ny combination of learning delivery methods which include face-to-face instruction with asynchronous and/or synchronous computer technologies (Osguthorpe and Graham 2003).

\subsection{Blended learning}

As Mortera-Gutierrez (2005) outlined that blended learning has been defined in different ways in the literature but in general, it is the combination of multiple approaches to learning, combining several different delivery methods, such as collaboration software, web-based courses or computer communication practices and traditional face-to-face instructions (Osguthorpe and Graham 2003). In the same context, Kerres and DeWitt (2003) defined blended learning as "Blended learning arrangements combine technology based learning with face-to-face learning and have become quite popular in different contexts" (p. 101). The authors discussed blended learning as the mix of different didactic methods and delivery formats which are independent.

Driscoll (2002), in a survey of literature, found four different uses prevalent:

$\checkmark$ combining or mixing of traditional face-to-face instruction with instructional technology;

$\checkmark$ combining of pedagogical approaches such as constructivism with behaviorism to produce an optimal learning outcome with or without instructional technology; $\checkmark$ combining any form of instructional technology such as CD ROMs with webbased technology with face-to-face instructor-led training and

$\checkmark$ combining instructional technology with specific tasks in order to create a harmonious effect of learning and working.

Driscoll, points out that blended learning means different things to different people, which illustrates its widely untapped potential (p. 54). Besides, Driscoll views blended learning as a strategy to gradually move learners from more traditional classroom settings to e-learning using incremental steps, thus making the change easier (as cited in Kerres and DeWitt 2003).

The term blended learning is also defined by Valiathan (2002) to describe a solution that combines several different delivery methods, such as collaboration software, Web-based courses, EPSS, and knowledge management practices. Blended learning also is used to describe learning that mixes various event-based activities, including face-to-face classrooms, live e-learning, and self-paced instruction." Fox's (2002) definition of blended learning is "... the ability to combine elements of classroom training, live and self-paced e-learning, and advanced supportive learning services in a manner that provides a tailored learning ..." (p. 26). 
Consequently, the different definitions of blended learning shows us diversity and strength of this type of learning. In this study, blended learning means integrating the online and face-to-face formats to create a more effective learning experience than either medium can produce alone.

The key question is how can we design a learning environment to ensure effective, efficient and flexible learning for the learner. Students' views is very important in order to asses efficiency and effectiveness of a learning environment. Students' views on a learning environment can be influenced by a number of factors such as their learning styles, self-efficacy, attitudes, motivations and interests. Therefore, when planning the use of learning media; the characteristics of the learners should be taken into account. Because, no single instructional technology is best for all learners. It is well known that no all students learn in the same way. Each person has specific preferences and strengths in the way they receive and process information presented to them. Learners will be able to achieve learning goals more efficiently, when learning environment are adapted or accommodated to their individual differences (Federico 1991).

Learning style, which is one of the basic characteristics of learners is also discussed in this study.

\subsection{Learning styles}

Since it is widely recognized that academic achievement depends not only on the intellectual ability and aptitude of the learner but also on the individual's learning styles (Kolb 1984), this topic has increasingly been studied by many educators in recent years. As mentioned in Frederico's study (2000), no single instructional strategy is best for all students. "Students will be able to achieve learning goals more efficiently, when pedagogical procedures are adapted or accomodated to their individual differences".

Newby et al. (2000) define learning style as 'the use of different methods by individuals while processing and arranging the information as well as reacting to environmental stimuli'. Keefe (1987) defines learning style as the 'mixture of cognitive, emotional and psychological characteristics of individuals which are, to some extent, coherent indicators of how individuals perceive their surroundings, how they interact with and react to learning media (Hood 1995). According to Kolb (1984), learning style is the method preferred by an individual during the recognition and processing of a specific piece of information. Therefore, learning style has both an emotional and a mental dimension. There are numbers of ways of looking at learning styles and various labels and descriptions for the individual elements. Within the scope of the research which constitutes the basis of this study, Kolb's Learning Style and his four categories which have widely been used in research on distance learning or web based learning and adult education (Kolb 1986; Diaz and Cartnal 1999; Miller 2005; Liegle and Janicki 2006; Sun et al. 2007).

\subsection{Kolb's learning style}

Kolb's Learning Style Model states that learning is a combination of experience, cognition, perception and behavior. In his model, Kolb classified the learning styles 
into four areas: Concrete experience, reflective observation, abstract conceptualization and active experimentation and

Learning methods applied in each learning style are different from each other. "Learning through experiencing" is suitable for "concrete experience"; "learning through observation" is suitable for "reflective observation"; "learning through thinking" is suitable for "abstract conceptualization" and "learning by doing" is suitable for "active experimentation" and gives the priority to learning through experience rather than theory and generalizations. Personal experiences, interactions with other people, concrete experience, discussions held in peer groups, receiving feedback and individual studies are among the most frequently used learning activities in this learning style employs a careful observation and definition process in order to conceptualize the ideas and conditions. There are also some perspectives on what would happen if individuals who prefer this learning style which adopts observation and listening, in the event that opposite ideas or situations emerge. Individuals learning this way, prefer activities which offer them an observer's role, and direct instruction technique, testing methods which include objective test expressions measuring the learning and knowledge.

Individuals preferring learning style focus on logic and ideas rather than feelings while solving problems or attribute meanings to conditions. They think of systematic plans and make use of theoretical information while solving a particular problem. Due to the fact that these individuals learn through thinking, individual studies, logical analysis of ideas, cognitive activities are the methods they would employ while assessing the conditions

In the learning style, individuals are active in terms of changing the conditions and influencing the experiences. These individuals are determined to finish any task they are given and consequently they would like to see their influence and signs of creativity in a completed task. Therefore, the most ideal way for these individuals is to learn by doing. They do not hesitate in taking risks, they like to influence the events and other individuals around them and they are practical people.

Learning styles in Kolb's model can be categorized as; assimilators, accommodators, divergents and convergers.

The Accommodator learning style includes concrete experience and active experimentation. Individuals preferring this learning style learn by doing and feeling. They like new experiences and planned work. Instead of intellectual analysis, they prefer to act on feelings. They like collecting information through dialogues with people, rather than gathering the necessary information through technical analysis

The Divergent learning style is suitable for individuals with high scores in the areas of concrete experience and reflective observation. These individuals are capable of assessing concrete events from different angles. They are more like observers rather than activists

The Assimilator learning style includes abstract conceptualization and reflective observation. Individuals bearing the characteristics of this type of learning are capable of grasping a large scale of information scattered over a wide discipline and convert it to a logical whole. Instead of dealing with other individuals, they prefer to deal with abstract concepts and issues. They generally focus on the logical validity of theories instead of their applicability. It is stated that the characteristics of these individuals could be developed through conducting research on the organization of information, establishing conceptual 
models, testing and confronting the ideas and theories, designing tests, conducting quantitative data analysis

The Converger learning style is seen when an individual prefers both abstract conceptualization and active experimentation. Individuals learning in this way are quite successful in terms of the practical application of ideas and theories, solving problems and making decisions. They prefer technical tasks and problems to social relations

Learning styles are not constant and, indeed, change over time. Therefore, it would be much more suitable if the methods and strategies to be adopted, class environment, teaching materials were selected and arranged taking into account the different learning styles. This is of course is easier and more efficient than expecting the students themselves to adapt to the learning environment. Moreover, as is stated above, if the learning media is prepared in accordance with the characteristics (learning styles, self-efficacy perception, attitudes, motivations etc.) of the students, the individuals learning experience will be more effective. Learning styles are significant in the preparation and use of blended learning media, therefore, this study focuses to learning styles of the learners.

Even though Coffield et al. (2004) suggested that Kolb's Learning Style Inventory (LSI) in general 'should not be used for individual selection'. Referring to the validity and reliability of LSI, the paper indicated that 'the construction validity of the LSI has been challenged and there is a long public dispute over reliability of LSI, in this research Kolb's learning style inventory has been chosen for several reasons. First of all, Kolb's (1986) learning style inventory, which is often used in distance learning research (Dille and Mezact 1991; Terrell and Dringus (2000); Frederico 2000; Fahy 2005; Lu et al. 2007) measures student preferences in two bi-polar dimensions. Kolb proposed that learners develop a preference either for concrete experiences or for engaging in abstract analyses when acquiring skills and knowledge over time. Students also may emphasize interest in turning theory into practice by active experimentation, or they may prefer to think about their experiences by reflective observation (Tongdeelert 2003).

Kolb's learning style inventory is also used for grouping learners because Kolb's learning style categorizes type of learners based upon their learning experiences. Blended learning are considered as a new learning environment, and learning experiences are very important in new learning environments.

The purpose of this study was to explore the students' view on blended learning and its implementation, in accordance with their learning styles. These are considered as an important issue for blended learning environment, whether by students, teachers and instructional designers.

\subsection{Review of literature}

Some studies analyzed Kolb's learning style and web based learning or blended learning addressed in this article (Terrell and Dringus 2000; Buch and Bartley 2002; Simpson and Du 2004; Richmond and Liu 2005, Liegle and Janicki 2006; Manochehr 2006; Lu et al. 2007; Michalski 2008; Unterberg 2009).

Terrell and Dringus (2000) tracked information science students during an online masters degree program. At their initial orientation, each student completed a demographic data form and the Kolb Learning Style Inventory. Students would fall 
into Kolb's Converger and Assimilator categories. The majority of students can succeed in an online learning environment regardless of their learning style. An exploratory study investigated the relationship between learning style and preference for training delivery mode (Buch and Bartley 2002). It was expected that learning style would influence learners' preference for receiving training through classroom-, computer-, TV-, print-, or audio-based delivery modes. Results found support for the expected relationship between the two, with convergers showing a stronger preference for computer-based delivery and assimilators showing a stronger preference for print-based delivery. However, results also revealed an overall preference for classroom-based delivery for adults in the study, regardless of their learning style. Simpson and $\mathrm{Du}$ (2004) explored the effect of Kolb learning styles on students' online participation and self-reported enjoyment levels in distributed learning environments. Multiple regression analysis found that learning style had a significant impact on the students' participation and enjoyment level. Results obtained study shows similarity with Buch and Bartley's research (2002). In their research, that convergers showing a stronger preference for on-line environment. Fahy (2005) investigated the relations between online behaviour and Kolb Learning style. In the study convergers showed their willingness to spend more time and the energy on the network. However, Richmond and Liu's study (2005) reached opposite conclusions. They evaluate the distribution of learning styles of students in online distance education courses versus those who are enrolled in traditional in-class courses. Students learning styles were determined as convergent, divergent, assimilative, or accommodative respectively. The analysis revealed no significant differences in distribution of learning styles in online distance education courses versus students enrolled in traditional courses. Liegle and Janicki (2006) analyzed the results of an exploratory experiment completed by 58 subjects. It first measured their learning style preferences (using a version of the Kolb Learning Style Inventory Tool) and compared it to their actual visits of linked Web-pages. The study found that learners classified as "Explorers" tended to "jump" more and created their own path of learning (learner control), while subjects classified as "Observers" tended to follow the suggested path by clicking on the "Next" button (system control). In addition, test scores for explorers who did jump were higher than explorers who did not jump, while conversely observers who did not jump scored higher than observers who did jump. In Manochehr's study (2006), the effects of e-learning versus those of traditional instructor-based learning, on student learning, based on student learning styles were compared. Another goal was to determine if e-learning is more effective for those with a particular learning style. The Kolb Learning Style Inventory (LSI) was used to measure the learning styles of students. The results showed that for the instructor-based learning class (traditional), the learning style was irrelevant, but for the web-based learning class (e-learning), the learning style was significantly important. Lu et al. (2007) examined the relationships between Kolb Learning Style and the enduring times of online learning behaviours, the relationships between Kolb Learning Style and learning outcomes and enduring times of online learning. Results showed that there was a significant effect between Kolb Learning Style and learning outcomes. Convergers and Assimilators' learning outcomes were higher than Divergers and Accommodators' learning outcomes. Although there are differences 
in the results of the studies, most emphasized the importance of student learning style to design learning environment. As Maddux et al. (2002) and Thiele (2003) have noted, it is increasingly important to identify student learning styles and adopt online course design to accommodate these styles. Michalski's paper (2008) addresses the way to go about learning styles of distance learning students and how to develop blended teaching materials to accommodate different learning styles in distance education environment. In the paper, it is suggested that before develop materials in blended ways, instructors have to know who their students are, and how they learn, in other words what their learning styles are. The purpose of the Unterberg (2009) study was to compare the learning outcomes of students in a specific course, given different learning environments and different learning styles. The learning environments were the in-classroom environment and the computer-mediated distance environment. Kolb's learning style was used. The relationships among education outcome, learning style, and learning environment were determined by comparing the percentages of above-average grades between the individual learning style groups and the learning environments. The researcher concluded that the classroom or distance environment did not influence learning outcome; however, the Diverger learning style may have a positive relationship to learning in the distance environment. Students who are Divergers tend to view concrete situations from many different points of view before taking immediate action. In the computer-mediated environment, students would have more opportunity to observe.

\section{Method}

This research adopted a comparative - casual approach to examine the relationship between the individual learning styles of a group of university students and their views on blended learning and its implementation in teaching context. The following questions were addressed.

a) What do the students think on blended learning and its implementation?

b) Do views of students on blended learning and its implementation differ according to the their learning styles?

\subsection{Study group}

The study group of this study was composed of 31 senior students attending the Department of Information and Document Management, Hacettepe University. The study group received the elective course on "Information Literacy". When the learning styles of the students were examined, it became clear that $61 \%$ of the students fell into the group of assimilators, $19.5 \%$ were convergers, and $19.5 \%$ were accommodators. The fact that majority of the students were assimilators and the study group was composed of students studying information and document management reflect the relationship between learning styles and occupational preferences. This supports Kolb's (1984) assertion that "librarianship" careers generally prefer "assimilators" learning styles. Since students in the study are from Department of Information and Document Management, it naturally follows they 
would fall into one of predicted categories. These learners can absorb a wide range of information when it is presented in an organized format. They also prefer individual reflection over class discussions (Felder 1996).

\subsection{Data collection tools}

In order to find the necessary answers to the questions posed in this study,

- Pre-Information Form

- Kolb's Learning Style Inventory and

- A Scale On Learners' Views On Blended Learning And Its Implementation Process were used to collect data and evidence.

Moreover, students' views on several aspects of the course were also gained through open-ended questions posed during different times in the semester.

\subsubsection{Pre-information form}

This includes questions concerning their personal information and whether students have previously attended courses where blended learning method was used. The PreInformation Form, prepared by the researcher, was handed out to students at the beginning of the semester.

\subsubsection{Kolb’s learning style inventory}

In this study, in order to determine the learning style of each student, Kolb's Learning Style Inventory (1986) which had been adapted and translated into Turkish by Așkar and Akkoyunlu (1993) was used. The inventory consists of 12 questions each with 4 options. Students are requested to assign a score (from 4 to 1 ) to each expression; starting from the most likely to the least likely. When the sum of these scores is taken, a value for each learning style is found. These values range from 12 to 48 . The reliability coefficient of the Inventory was determined as $\alpha=.73$ (Așkar and Akkoyunlu 1993, 42).

\subsubsection{Scale on learners' views on blended learning and its implementation process}

This scale developed by Akkoyunlu and Y1lmaz-Soylu (2006, 2008) consists of 50 expressions and with scores from 1 to 10 . There are two main sections, the first 35 expressions aim to highlight the learners' views on blended learning's implementation (easy use of web media, online media, content, face to face media, blended learning method and evaluation) whereas remaining 15 expressions aim to determine learners' views on blended learning in general.

On a ten-point Likert scale, anchored with notations $0=$ not at all and $10=$ totally true. The students were asked to assign a score between $1-10$ for each expression. From " $1-5$ " is regarded as "low", from "5.01-7" as "Medium" and from "7.01-10" as "High". In order to ensure a high reliability, the test repeat method was used and the alpha reliability coefficient of the first section was determined as $\alpha=.78$, for the second section as $\alpha=.79$ and in general as $\alpha=.78$ (Akkoyunlu and Y1lmaz-Soylu 2006, 2008). 


\subsubsection{Open-ended questions}

These questions aimed to quantitatively determine the views of students on blended learning and its implementation and then address them in detail. Openended questions were posed at the beginning of the semester in order to clarify the expectations of the students from the blended learning. In the middle of the semester, open-ended questions were asked again in order to highlight any difficulties they had met or benefits they gained with regard to the courses given in blended learning environment. The open ended questions posed at the end of the semester were designed to elicit the views of students in terms of the contribution of the blended learning to their studies and its relationship to their study habits.

\subsection{Research process}

The "Information Literacy" course lasted 14 weeks (1 semester) consisted of face to face media and web media. One week the students received the course over the web (studying the course notes and questions for lesson preparation provided on internet), the next week they were exposed to face to face education for two hours. Prior to the lesson, students were asked to read the course notes pertaining to that week's content provided on the internet, reflected on discussion questions and submitted the written answers to discussion questions as they started the lesson. A website and a forum were devoted to this course and students entered to the website with a user name and password. The forum acted as a platform where students could communicate with each other and with the lecturer. Moreover, it was also used as a platform where preparation for the lesson, prediscussion, information exchange could be made and where students could help each other. In the face to face lessons, the topic of the week was determined in the light of discussion questions, points which could not be understood by students previously were discussed face to face and resolved. Learning materials designed by researchers were used in presentations and they were also available on the internet upon the request of the students.

\subsection{Data analysis}

Descriptive statistics and covariance analysis ANCOVA were used with a significance level of .05. Besides, students gave written answers to open ended questions and these answers were stored in electronic files. Filed texts were classified according to their learning styles and evaluated.

\section{Findings and discussions}

In this part of the article, findings are presented and discussed with questions posed in the study. Students' views obtained through open ended questions were also translated from Turkish by the authors. 
3.1 What are students' views on blended learning and its implementation?

The average values pertaining to the students' views on the blended learning and its implementation are presented in Table 1, where it can be seen that the mean score of the students' views regarding blended learning implementation is 8,66 . When the students' views on the blended learning in general is taken into consideration, the mean score becomes 7,57. As mentioned above, students were asked to assign a score between $1-10$ for each expression. 1 - 5 was regarded as low, 5.01-7 as "Medium" and 7.01-10 as High. Accordingly, it would be appropriate to state that the students have a highly positive opinion on blended learning and its implementation.

Since the overall mean score of the students' views on the blended learning is 8,34 , students have a highly positive opinion on the blended learning method. This is also valid for the answers given to the open ended questions. For example, one student said:

"This has been the most efficient and easiest lesson to understand so far. We had the opportunity to participate in discussion topics in the forum. I had the chance to express my opinion. I was able to understand Information Literacy course without having to memorize any concept."

This level of motivation and engagement is reflected in other studies, for example, Langley's study (2004) gave this comment by a student; "The content was sufficient as we are provided with all the information needed. (...) I would feel like I was learning more by reading it for myself. I would access the other sources. I had a chance to participate in discussion topics in the form and made me happy" (p. 161).

The results of the students' views on the sub categories of blended learning implementation are provided in Table 2.

The average values from highest to lowest were "assessment concerning the content" (9.08), "face to face sessions" (8.96), "content" (8.72), "Ease of use for web environment" (8.56) and "On-line environment" (8.03) respectively. Students are generally very positive about their views on all of the sub categories. The results are also parallel to answers given to the open ended questions. Below are four students views regarding the sub categories of the implementation:

"As I prepare for the lessons by reading the course notes in advance, I can easily understand the lesson. I manage to remember most of the lesson content when the lesson is over. I do not encounter any difficulty at the synthesis level as I had in the first assignment".

"Discussions held in the classroom are beneficial and make it easier and more beneficial for us to understand the lesson. When the lesson is presented in such

Table 1 Students' views on the blended learning and its implementation

\begin{tabular}{lcrr}
\hline Dimensions & $\mathrm{N}$ & $\bar{x}$ & $\mathrm{Sd}$ \\
\hline Implementation of blended learning & 31 & 8.66 & 0,78 \\
Blended learning in general & & 7.57 & 0,80 \\
Overall & & 8,34 & 0,70 \\
\hline
\end{tabular}


Table 2 Descriptive statistics of students' views on the sub categories of blended learning implementation

\begin{tabular}{|c|c|c|c|}
\hline Sub categories & $\mathrm{n}$ & $\bar{x}$ & sd \\
\hline Easy use of Web Environment & 31 & 8,56 & 1,45 \\
\hline Online Media Environment & & 8,03 & 1,65 \\
\hline Content & & 8,72 & 1,02 \\
\hline Face to Face Sessions & & 8,96 & 0,74 \\
\hline Assessment concerning the content & & 9,08 & 1,22 \\
\hline
\end{tabular}

media, we are able to establish a firmer connection between the topics and look from a wider perspective".

"It is very important to hold discussion sessions in the face to face lessons because students are exposed to different ideas and opinions and also enjoy the opportunity of expressing themselves freely and openly. Moreover, in the face to face setting, different aspects of the topic could be seen".

"Different ideas ensure an integration of the lecturer's thoughts and theoretical information provided in the web media. It also ensures better learning".

According to a study conducted by Rovai and Jordan (2004), the students' view on the blended learning implementation is much more positive than traditional or e-learning. Moreover, a study conducted in Turkey by Akkoyunlu and Yilmaz Soylu (2006), concerning the undergraduate students of the Department of Computer Education and Instructional Technologies shows that all students of this department have a positive attitude towards blended learning. Orhan (2008) discussed the process of redesigning a course for blended learning and to exploring the university students' perceptions of Blended Learning Environment (BLE). In the study, the comments from the students indicated that they would not want to continue their education solely with traditional face-to-face learning environments or with a purely online learning environment. At the University of Wisconsin, Milwaukee campus, $80 \%$ of the total students who took a blended learning course indicated they thought the experience was worthwhile and they would recommend a course offered in a blended format to others (Aycock et al. 2002). These prove that blended learning media combines the advantages of both media

The second question posed in the study was discussed in 3.2.

3.2 Do students' views on the blended learning and its implementation differ according to their different learning styles?

Whether the students's views on blended learning method and its implementation differ according to their different learning styles was also analyzed in covariance analysis (ANCOVA). The results are shown in Table 3.

When the descriptive statistical results shown in Table 3 are taken into account, it is evident that highest positive value towards blended learning implementation comes from the Accommodator group. As for the implementation of the method, 
Table 3 Descriptive statistics of students' views with different learning styles on the blended learning and its implementation

\begin{tabular}{llrrr}
\hline & Learning Style & $\mathrm{n}$ & $\bar{x}$ & Sd \\
\hline Blended learning implementation & Assimilator & 19 & 8,53 & 0,84 \\
& Converger & 6 & 8,77 & 0,79 \\
& Accommodator & 6 & 8,98 & 0,64 \\
& Overall & 31 & 8,66 & 0,79 \\
Blended learning in general & Assimilator & 19 & 7,51 & 0,77 \\
& Converger & 6 & 7,58 & 0,90 \\
& Accommodator & 6 & 7,73 & 0,85 \\
& Overall & 31 & 7,57 & 0,78 \\
\hline
\end{tabular}

again the Accommodator group ranks highest. The result can be explained with their learning styles. Accommodators learn through concrete hands-on experiences (Holley and Jenkins 1993) and active experimentation. They like being involved in new and challenging situations, and can be expected to follow their "gut feelings" over logical analyses (Kolb 1984). They favor problem-based learning, wherein the instructor assigns open-ended questions and allows the students to discover things on their own (Felder and Brent 2005). The blended learning and its implemantions can be new situation for them. However, as can be seen in Table 3, the mean scores of students in the Assimilator, Converger and Accommodator groups are very close to each other. In order to determine whether the scores assigned by the students differ in accordance with their learning styles, covariance analysis (ANCOVA) was made and results are given in Tables 4 and 5.

As seen in Table 4, no meaningful difference was detected in terms of the students' having different learning styles and their views $(p=.070>.05)$ on the use of the blended learning in general. The effect size of the research is (over eta square) .220 which indicates a high effect size. The strength of the research has been calculated as .759 . In the light of this data, it can be claimed that the research is not only statistically meaningful, but also practically meaningful as well.

Table 4 ANCOVA for students' views on blended learning implementation regarding their learning styles

\begin{tabular}{lrrrrrrr}
\hline Resource of the Variance & KT & sd & KO & F & (p) & Eta Square & Strength \\
\hline Corrected Model & 4,973 & 3 & 1,658 & 3,202 &, 039 &, 262 &, 673 \\
(Intercept) & 12,704 & 1 & 12,704 & 24,543 &, 000 &, 476 &, 998 \\
Learning Style & 3,950 & 1 & 3,950 & 7,630 &, 010 &, 220 &, 759 \\
Success & 3,050 & 2 & 1,525 & 2,946 &, 070 &, 179 &, 526 \\
Error & 13,976 & 27 &, 518 & & & & \\
Total & 2345,371 & 31 & & & & & \\
Corrected Total & 18,948 & 30 & & & & & \\
\hline
\end{tabular}


Table 5 ANCOVA for students' views on blended learning in general regarding their learning styles

\begin{tabular}{lccccccc}
\hline Resource of the Variance & KT & Sd & KO & F & (p) & Eta Square & Strength \\
\hline Corrected Model &, 225 & 3 & $7,486 \mathrm{E}-02$ &, 111 &, 953 &, 012 &, 068 \\
(Intercept) & 22,62 & 1 & 22,625 & 33,531 &, 000 &, 554 & 1,000 \\
Learning Style &, 207 & 2 &, 103 &, 153 &, 859 &, 011 &, 071 \\
Success & $2,590 \mathrm{E}-$ & 1 & $2,590 \mathrm{E}-03$ &, 004 &, 951 &, 000 &, 050 \\
Error & 18,218 & 27 &, 675 & & & & \\
Total & 1794,28 & 31 & & & & & \\
Corrected Total & 18,443 & 30 & & & & & \\
\hline
\end{tabular}

According to the ANCOVA analysis results shown in Table 5, no meaningful difference is detected in terms of the views of students with different learning styles $(p=.859>.05)$ on the blended learning and its implementation.

The effect size of the study (eta square) is .011which indicates a low effect size, however, the strength of the study is calculated as .071. Therefore, the effect size of the study is low however, the strength of the study is high. The study results showed that students' views on blended learning and its implementation are highly positive. The views of the students falling within the groups of Accommodator, Assimilator and Converger learning styles are also similar. Students' answers obtained from open ended questions have supported the results.

Student responses to the questions about difficulties met during the Information Literacy course:

Assimilator: "So far, I have not encountered any difficulty in a lesson delivered by blended learning method",

"I have not faced any difficulty"

Converger: "I haven't encountered any difficulty or problem"

Accommodator: "There is no difficulty at all"

Some examples of student responses to the question concerning the benefits introduced by the method are given below:

Assimilator: "We have the notes before coming to the lesson which helps us better understand what is being explained. Moreover, discussions are held in the lessons and we can better learn the content through this discussion. I believe it will be very beneficial for the exams as well",

"As I prepare for the lesson, I can easily recall the lesson contents. Moreover, I find it much easier to follow the lesson when I have the chance to read the course notes and get prepared for the lesson in advance."

"The experience is better when different applications and technologies are used to support the instruction"

Converger: "Our perspective widens. I can handle the events from a different point of view. There is no need to memorize the concepts which is very comforting. This style of education is really based on learning",

"As we have the chance to review the content of the coming lesson, we can effectively participate in the lesson. Therefore I do not have to do extra 
work for the exams. Thanks to the synthesis method, there is no need to memorize everything!"

Accommodator: "This lesson has a theoretical content, however through this method, it was made so modern and effective that I was totally able to understand the whole lesson and concepts. I can add a lot to my own ideas through listening to your and my friends' ideas. I also prepare for the lesson in advance"

When the students' from the different learning style groups were asked about the online environment, they presented similar views;

Assimilator: "As it is based on visual elements, it is much more effective and easier to remember. Finding the relevant information, accessing it are easier in web media",

"I can access all the relevant materials over the internet and get answers to all of my questions"

Converger: "Thanks to the developing technology, I can easily access information from any media",

"Education through web media changed my attitude towards homework, assignments and lessons in a positive way. Although it takes more time, I can comfortably prepare for the lessons at home".

"In the online environment I felt creative, and felt comfortable in sharing my opinions"

Accommodator: "The fact that course notes are available on the internet makes it easier to access information",

"Thanks to fast internet access, making use of web media is a great opportunity offered to us. Moreover, the forum is very useful in terms of the exchange of ideas and thoughts".

The results showed that most students perceived differences between blended learning and traditional method. Some of their views are given below;

Assimilator: "Before the information and knowledge provided in the lessons was prepared and presented by the teacher and we used to take notes. However, this type of learning includes skills such as making comments on what is being discussed, critical thinking, and active participation in the lesson",

"I think it is very different and unique because it constitutes active learning. Moreover, we have the web option which we can access any time we like. I think this is quite different from our previous learning habits",

"So far, I have received my education which stipulated a system where we used to sit, wait for the instructor, listen to him/her and finally do the homework assigned. However there are many more advantages in learning new and different things with this model."

Converger: "Our previous learning practices depended merely on memorizing the lesson content. This was not sufficient for permanent learning. Blended learning contributes greatly to learning skills as well as other skills",

"Other learning methods did not provide permanent learning. They were not very informative either. Practice makes sense and facilitates the learning process". 
Accommodator: "I think it is quite different from other learning habits because it enables me to analyze and transfer the right information and express my thoughts in an open discussion forum".

From these comments which are representative of a the majority of the students in the study it can be seen that generally the students perceived blended learning much flexible and student oriented. It appears that they preferred blended learning to only face to face teaching. The results showed that in relation to their learning style the students' views on blended learning and its implementation were all highly positive and therefore not significantly different. However, the responses obtained from open ended questions showed that the Assimilators showed their willingness to participate in the Blended Learning method more than the other three learning style types.

\section{Conclusion}

Quality of learning depends on several factors or dynamics such as meeting students' needs, their learning styles, preferences etc. In order to enhance the quality of learning, first step should be analyze their learning styles. Therefore, this study aimed to examine students' views on blended learning and its implementation in terms of their learning styles.

All the students in the study group fell into the following three of the four categories, assimilator, accommodator and converger, according to in Kolb's category. Kolb learning model indicates learning style norms in academic disciplines. Assimilators have strong ability to create theoretical models and concerned with abstract concepts rather than people; accommodators have greatest strength at doing things, perform well when required to react to immediate circumstances and convergers Convergers are people who perceive reality through abstract conceptualisation, and process it through active experimentation. Their strength is applying ideas and they use deductive reasoning to arrive at answers (Kolb and Fry 1975).

The mean score of the students' views regarding the use of blended learning and its implementation is "highly" positive. The results were supported by answers given to the open ended questions.

Students were also generally very positive about their views on all of the sub categories (easy use of web environment, online environment, content, face to face sessions, assessment concerning the content).

As some authors have underlined (Richmond and Liu 2005, Liegle and Janicki 2006; Lu et al. 2007) that an effective course design must integrate the principles of learning cycle, learning styles to be more effective, the learning environment must support individual learning preferences and be able to present activities adequate to each student. That is why, in this study, the students' view on blended learning and its implementation, in accordance with their learning styles was examined. However, the results of the covariance analysis (ANCOVA) showed that there were no differences between students' views on blended learning and its implementation regarding their learning styles. Students' responses to the open ended questions also supported the results. 
The size of the study group was so small and the participants only consisted of three of the four learning style types, therefore, further studies with a bigger sample size student population includes four learning styles are suggested.

\section{Limitations}

One of the limitations of the study was the participants' learning style were assimilators, accommodators and convergers learning styles with a small size group. Furthermore the distribution over those three groups was irregular.

The other limitation was the utilization of a non - probability sampling technique which is used when it is impossible or impractical to use random sampling techniques. Thus the case is limited in a large portion of educational research. While still valid, the results should not be over generalized.

\section{References}

Akkoyunlu, B., \& Soylu, M. Y. (2006). A Study on students' views on blended learning environment. Turkish Journal of Distance Education, 7(3), 43-56.

Akkoyunlu, B., \& Soylu, M. Y. (2008). Development of a scale on learners' views on blended learning and its implementation process. The Internet and Universities., 11, 26-32.

Așkar, P., \& Akkoyunlu, B. (1993). Kolb learning style inventory. Education and Science, 87, 37-47.

Aycock, A., Garnham, C. \& Kaleta, R. (2002) Lessons learned from the hybrid course project. Teaching with technology, 8. http://www.uwsa.edu/ttt/articles/garnham2.htm. Accessed 15 November 2006.

Bliuc, A. M., Goodyear, P., \& Ellis, R. A. (2007). Research focus and methodological choices in studies into students' experiences of blended learning in higher education. Internet and Higher Education., 10, 231-244.

Buch, K., \& Bartley, S. (2002). Learning style and training delivery mode preference. Journal of Workplace Learning, 14(1), 5-10.

Caldwell, J., Toman, N., and Leahy, J. (2006) Diversity and difference in the learning experience of students in contemporary mass Higher Education. Paper presented at NUI Galway 4th Annual Conference on Teaching \& Learning 8-9 June 2006.

Coffield, F., Moseley, D., Hall, E., \& Ecclestone, K. (2004). Learning styles and pedagogy in post-16 learning: A systematic and critical review. www.LSRC.ac.uk: Learning and Skills Research Centre. http://www.lsda.org.uk/files/PDF/1543.pdf Access Retrieved May, 2007.

Diaz, D. P., \& Cartnal, R. B. (1999). Students' learning styles in two classes: Online distance learning and equivalent on-campus. College Teaching, 47(4), 130-135.

Dille, B., \& Mezack, M. (1991). Identifying predictors of high-risk among community college telecourse students. The American Journal of Distance Education, 5(1), 24-35.

Driscoll, M. (2002). Blended Learning: Let's get beyond the hype. elearning, March, 54

Fahy, P. J. (2005). Student learning style and asynchronous computer-mediated conferencing (CMC) interaction. TheAmerican Journal of Distance Education, 19(1), 5-22.

Fox, M. (2002). The blended promise (pp. 27-30). March: E-Learning.

Federico, P. A. (1991). Student cognitive attributes and performance in a computer — managed instructional setting. In R. Dillion \& J. Pellegrino (Eds.), Instruction: Theoratical and applied perspectives (pp. 16-46). New York: Praeger.

Federico, P. (2000). Learning styles and student attitudes toward various aspects of network-based instruction. Computers in Human Behavior, 16, 359-379.

Felder, R. M. (1996). Matters of style. ASEE Prism, 6(4), 18-23.

Felder, R. M., \& Brent, R. (2005). Understanding student differences. Journal of Engineering Education, 94(1), 57-72.

Ginns, P., \& Ellis, R. (2007). Quality in blended learning: Exploring the relationships between on-line and face-to-face teaching and learning. Internet and Higher Education, 10, 53-64. 
Hood, K. (1995) Exploring learning styles and instruction. http://jwilson.coe.uga.edu/emt705/EMT705. Hood.html. Accessed Retrieved 15 November 2006.

Holley, J. H., \& Jenkins, E. K. (1993). The relationship between learning style and performance on various test question formats. Journal of Education for Business, 68, 301-308.

Karadeniz, Ș. (2009). Flexible design for the future of distance learning. Procedia Social and Behavioral Science, s 1, 358-363.

Keefe, J. W. (1987). Learning style theory and practice. VA: Reston.

Kennedy, D., \& McNaught, C. (1997). Design elements for interactive multimedia. Australian Journal of Educational Technology, 13(1), 1-22.

Kerres, M., \& DeWitt, C. (2003). A didactical framework for the design of blended learning arrangements. Journal of Educational Media, 28(2-3), 101-113.

Kolb, D. A., \& Fry, R. (1975). 'Toward an applied theory of experiential learning. In C. Cooper (Ed.), Theories of Group Process. London: John Wiley.

Kolb, D. A. (1984). Experiential learning: Experience as the source of learning and development, Upper Saddle River. Prentice Hall: N. J.

Kolb, D. A. (1986). Learning Style Inventory: Technical Manual (Revth ed.). Boston, MA: McBer.

Langley, A. (2004) Experiential learning, e-learning and social learning: The EES approach to developing blended learning. Education in a Changing Environment Conference Paper. 13th -14 th September 2004. 158 - 164. http://www.ece.salford.ac.uk/proceedings/papers/18_07.pdf Accessed 15 November 2006.

Liegle, J. O., \& Janicki, T. N. (2006). The effect of learning styles on navigation needs of web-based learners. Computers in Human Behavior, 22(5), 885-898.

Lu, H., Jia, L., Gong, S. H., \& Clark, B. (2007). The relationship of Kolb learning styles, online learning behaviors and learning outcomes. Educational Technology \& Society, 10(4), 187-196.

Maddux, C. D., Ewing-Taylor, J. F., \& Johnson, D. L. (eds). (2002). Distance Education: Issue and concerns. New York: The Howarth Press.

Miller, M. L. (2005). Using learning styles to evaluate computer based instruction. Computers in Human Behaviour, 21(2), 287-306.

Manochehr, N. N. (2006). The influence of learning styles on learners in e-learning environments: An empirical study. CHEER Virtual Edition, 18, 10-14.

Michalski, K. (2008). Learning styles and blended learning. Challenges and opportunities in distance education environment. In Proceedings of World Conference on Educational Multimedia, Hypermedia and Telecommunications. 4290-4297. Chesapeake, VA: AACE. Retrieved from http://www.editlib.org/p/ 28980.

Mortera-Gutierrez, F. J. (2005). .Faculty best practises using blended learning in e - learning and face to face instruction. 20th Annual Conference on Distantance Teaching and Learning. Madison, Wisconsin

Newby, T. J., Stepich, D. A., Lehman, J. D., \& Russell, J. D. (2000). Instructional technology for teaching and learning: Designing instruction, integrating computers, and using media (2nd ed.). Columbus, $\mathrm{OH}$ : Merrill.

Oblinger, D., \& Hawkins B. (2005). The myth about e-Learning. We don't need to worry about e learning anymore. EDUCAUSE Review, 40(4), 14-15.

Oliver, R., \& Short, G. (1996). The Western Australian Telecentres Network: A model for enhancing access to education and training in rural areas. International Journal of Educational Telecommunications, 2(4), 311-328.

Orhan, F. (2008) Redesigning a course for blended learning environment. Turkish Online Journal of Distance Educatio 9(1) Article 3. http://tojde.anadolu.edu.tr/tojde29/articles/article_3.htm. Accessed 5 March 2008.

Osguthorpe, R. T., \& Graham, C. R. (2003). Blended learning systems: Definitions and directions. Quarterly Review of Distance Education, 4(3), 227-234.

Prensky, M. (2001). "Digital natives, digital immigrants." On the Horizon. NCB University Press. 9(5).

Raines, C. (2005). Meet the generations. http:/www.generationsatwork.com/prereading.htm. Accessed 8 July 2009.

Simpson, C., \& Du, Y. (2004). Effects of learning styles and class participation on students' enjoyment level indistributed learning environments. Journal of Education for Library \& Information Science, 45(2), 123-136.

Toman, N.; Leahy, J. and Caldwell, J. (2005) The Learning Culture of Students in Contemporary Mass Higher Education. Proceedings of 3rd International Conference — What a Difference a Pedagogy Makes. 
Richmond, A., \& Liu, L. (2005). Student learning style of traditional courses versus online distance courses. In C. Crawford, et al. (Eds.), Proceedings of Society for Information Technology and Teacher Education International Conference (pp. 576-578). Chesapeake, VA: AACE.

Rovai, A. P. \& Jordan, H. M. (2004) "Blended learning and sense of community: A comparative analysis with traditional and fully online graduate courses." The International Review of Research in Open and Distance Learning, 5(2). http://www.irrodl.org/index.php/irrodl/article/viewArticle/192/274. Acccessed 6 June 2006.

Sun, K., Lin, Y., \& Yu, C. (2007). A study on learning effect among different learning styles in a web based lab of science for elementary school students. Computers \& Education. doi:10.1016/j. cpmpedu.2007.01.03.

Terrell, S. R., \& Dringus, L. (2000). An investigation of the effect of learning style on student success in an online environment. Journal of Educational Systems, 28(3), 231-238.

Thiele, J. E. (2003). Learning patterns of online students. Journal of Nursing Education, 42(8), 364-367.

Unterberg, M. (2009). Do learning style and learning environment affect learning outcome? Journal of Physical Therapy Education. http://findarticles.com/p/articles/mi_qa3969/is_200310/ai_n9269436/ Accessed 15 Aug, 2009.

Tongdeelert, P. (2003). A proposed collaborative computer network-based learning model for undergraduate students with different learning styles. Turkish Online Journal of Distance Education-TOJDE Volume:4 Number:4

Valiathan, P. (2002). Blended learning models. http://www.learningcircuits.org/2002/aug2002/valiathan Accessed 6 July 2009. 